AUTHORS:

Hangwani T.H. Muedi ${ }^{1}$

Deidre Fourie ${ }^{1}$

Neal W. McLaren²

\section{AFFILIATIONS:}

${ }^{1}$ Agricultural Research Council

- Grain Crops Institute,

Potchefstroom, South Africa

2Department of Plant Sciences,

University of the Free State,

Bloemfontein, South Africa

\section{CORRESPONDENCE TO:}

Hangwani Muedi

EMAIL:

MuediH@arc.agric.za

\section{POSTAL ADDRESS:}

Agricultural Research Council Grain Crops Institute, Private Bag X1251, Potchefstroom 2520, South Africa

\section{DATES:}

Received: 13 Jan. 2014

Revised: 25 Apr. 2014

Accepted: 25 July 2014

\section{KEYWORDS:}

incidence; national cultivar trial; severity; strip trial; survey

\section{HOW TO CITE:}

Muedi HTH, Fourie D, McLaren

NW. Distribution and severity of bacterial brown spot on dry beans in South Africa: An update. S Afr J Sci. 2015;111(3/4), Art. \#2014-0015, 6 pages. http://dx.doi.org/10.17159/ sajs.2015/20140015

(C) 2015. The Author(s). Published under a Creative Commons Attribution Licence.

\title{
Distribution and severity of bacterial brown spot on dry beans in South Africa: An update
}

\begin{abstract}
Bacterial brown spot (BBS) of common bean (Phaseolus vulgaris) is a seed-borne bacterial disease caused by Pseudomonas syringae pv. syringae (Pss). Dry bean is an important field crop in South Africa and all commercially available South African dry bean cultivars are susceptible to BBS. The aim of this study was to determine the current distribution and severity of BBS in the dry bean production areas of South Africa. We surveyed 31 locations in five provinces. Disease severity was evaluated on selected plots on a 0-9 scale in four different farming systems: commercial and subsistence farms and strip and national cultivar trials. Leaves with typical BBS symptoms were harvested and transferred to the laboratory. Bacteria were isolated following standard procedure using King's $B$ medium. Identification of pure isolates was done using physiological and biochemical techniques. Incidence and severity values were used to calculate a disease index. BBS was observed in $88 \%$ of locations. BBS incidence was recorded in $54 \%$ to $100 \%$ of all the farming systems surveyed during the 2008/2009 and 2010/2011 seasons combined. BBS was more severe in the strip and national cultivar trials than on subsistence and commercial farms during the 2008/2009 season and more severe on the commercial farm and in national cultivar trials than on subsistence farms and strip trials during the 2010/2011 season. Findings of this study signal the importance of developing BBS-resistant dry bean cultivars for South Africa.
\end{abstract}

\section{Introduction}

Bacterial brown spot (BBS), caused by Pseudomonas syringae pv. syringae (Pss), Van Hall, is an important bacterial disease of common bean (Phaseolus vulgaris L.) globally, including in South Africa. ${ }^{1-3}$ The disease is seed-borne and mainly infects foliage and to a lesser extent pods. It is prevalent where dry bean monocropping is practised and spreads through seed transmission, wind and human movement from infected to uninfected areas. ${ }^{4}$ PSs has a wide host range, infecting more than 180 host plant species including woody plants and weeds. ${ }^{5-7}$

On common bean leaves, BBS symptoms may first appear as water-soaked spots, which gradually enlarge and dry up, and are often surrounded by a narrow yellow or light green zone. Lesions may coalesce and occasionally abscise, subsequently giving the foliage a tattered appearance. ${ }^{6}$ Water-soaked spots may also appear on infected pods as circular and initially water-soaked spots, later becoming darker green and sunken brown and necrotic, and causing the infected area to bend as a result of cessation of growth on young pods at the point of infection. ${ }^{6}$ Occasionally, ring spots of lesions occur around a central lesion. ${ }^{8}$ Infected seeds initially have water-soaked spots and later become brown and shrivelled when infection is severe. ${ }^{9}$ Stem lesions appear when the pathogen develops systemically. ${ }^{8}$ Sources of inoculum include seed and infected volunteer beans ${ }^{10}$, weed hosts and plant debris ${ }^{11,12}$.

PSs has been widely reported in the USA, Brazil and Canada. ${ }^{1,11-13}$ The pathogen has also been reported in Algeria, Asia, Australia, Egypt, Europe, Ethiopia, Kenya, Lesotho, Malawi, Mauritius, Morocco, New Zealand, Tanzania, Tunisia, Uganda and Zimbabwe. ${ }^{14,15}$ Although Melis ${ }^{16}$ reported the incidence of BBS as being 'only occasional' in South Africa, the disease was first described in $1994^{17}$ when $100 \%$ incidence on the cultivar Bonus was recorded. Subsequent reports indicated BBS incidences as high as $93 \%$ in seed production fields and $100 \%$ in commercial fields, although severities were generally low ( $\leq 2$ on a 1-9 scale). ${ }^{2}$ The disease is more prevalent during the reproduction stage, gradually lessening as plants reach physiological maturity.

BBS epidemics are favoured by warm humid conditions ( $>95 \% \mathrm{RH}, 28-32{ }^{\circ} \mathrm{C}$ ) as well as thunderstorms and hail. 6,10 These conditions characterise the South African climate, especially in the central and eastern parts of the country, where dry beans are largely planted on commercial scale.

BBS management methods include the use of disease-free seed, application of copper-based fungicides, crop rotation, sanitation and avoiding working the field when wet. ${ }^{6}$ Copper-based fungicides only serve as a preventative measure and some Pss populations are resistant to copper sprays. ${ }^{18,19}$

Yield losses of up to $55 \%$ associated with BBS have previously been reported in South Africa. ${ }^{17}$ This loss remains a concern, mainly in commercial farming, because the crop has been reported as an important field crop on account of its nutritional composition ${ }^{20}$ and it is a staple food in the eastern parts of the country. Commercial annual dry bean production averages 65000 tonnes on approximately 50000 hectares.$^{21}$ Crops are composed mainly of red speckled sugar (65-75\%), small white canning (10-20\%) and large white kidney beans (5-10\%), and to a lesser extent of alubia (1-5\%) and carioca beans (3-5\%). ${ }^{22}$ Red speckled sugar beans also dominate the composition of beans grown by subsistence farmers. Although previous surveys were conducted in $2002,{ }^{2}$ recent documentation on the incidence of BBS on dry bean production farms and in research trials of South Africa is not available. The objective of this study was to quantify the distribution and severity of BBS on commercial and subsistence farms, as well as in strip and national cultivar trials of South Africa. These trials are planted annually to determine the performances of cultivars in the main bean producing areas. The information obtained from this survey is required to justify the necessity to embark on a BBS-resistance breeding programme and the deployment of effective means of BBS control in dry bean fields. 


\section{Materials and methods}

\section{Disease surveys in commercial fields}

Bacterial brown spot was surveyed in commercial dry bean fields from February to April during the 2008/2009 and 2010/2011 growing seasons to determine incidence and severity. A total of 32 fields at 20 localities (Table 1) was surveyed during flowering, early- and advancedpod stages. The incidence of plants showing typical BBS symptoms was assessed in 10 randomly selected groups of 10 consecutive plants amounting to 100 plants/field. Incidence and severity values were used to calculate a disease index $\left(D_{l}\right)$ using the model:

$\mathrm{D}_{1}=(I \times S) / M$

where $I$ is the incidence of diseased plants (\%), $S$ is the mean severity of foliar symptoms and $M$ is the maximum severity value (i.e. 9 ). ${ }^{23}$

\section{Disease surveys in strip trials}

Three strip trials were surveyed in March during the 2008/2009 and 2010/2011 dry bean growing seasons to determine BBS incidence and severity (Table 2). For each cultivar, 10 randomly selected plants were assessed for incidence and severity and $D$, was calculated as described above.

\section{Disease surveys in the national cultivar trials}

A total of 22 cultivar trials was surveyed for the incidence and severity of BBS at 12 localities during the 2008/2009 and 2010/2011 dry bean growing seasons (Table 3). The plants were evaluated as described above. Samples were collected from only severely infected plants.

Disease surveys on subsistence farms and home gardens Bacterial brown spot surveys on subsistence farms and in home gardens were done at eight localities during the 2008/2009 and 2010/2011 seasons (Table 4). Incidence of plants showing typical BBS symptoms

Table 1: Occurrence of bacterial brown spot in dry bean commercial fields of South Africa

\begin{tabular}{|c|c|c|c|c|c|c|c|}
\hline \multirow{3}{*}{ Location } & \multirow{3}{*}{$\begin{array}{l}\text { Altitude }^{\dagger} \\
\text { (m) }\end{array}$} & \multicolumn{6}{|c|}{ Season } \\
\hline & & \multicolumn{3}{|c|}{ 2008/2009 } & \multicolumn{3}{|c|}{ 2010/2011 } \\
\hline & & $I(\%)$ & S (\%) & $D_{l}(\%)$ & $I(\%)$ & $S(\%)$ & $D_{l}(\%)$ \\
\hline \multicolumn{8}{|l|}{ KwaZulu-Natal } \\
\hline Vryheid & 1190 & 10 & 1 & 5.0 & - & - & - \\
\hline \multicolumn{8}{|l|}{ Free State } \\
\hline Warden & 1375 & 8 & 3 & 6.0 & 5 & 3 & 5.0 \\
\hline Estcort & 1181 & 3 & 3 & 3.0 & - & - & - \\
\hline PetrusSteyn & - & 3 & 2 & 3.0 & 4 & 2 & 2.7 \\
\hline Sterkfontein & 1629 & - & - & - & 9 & 3 & 9.0 \\
\hline Reitz & 1615 & 6 & 1 & 3.0 & - & - & - \\
\hline \multicolumn{8}{|l|}{ Mpumalanga } \\
\hline Delmas & 1571 & 5 & 1 & 2.5 & 9 & 1 & 4.5 \\
\hline Ermelo & 1735 & 15 & 1 & 7.5 & - & - & - \\
\hline Ermelo West & 1735 & 8 & 1 & 4.0 & 9 & 1 & 4.5 \\
\hline Middelburg & 1447 & 9 & 1 & 4.5 & 5 & 1 & 5.0 \\
\hline Kriel & - & 7 & 1 & 2.3 & - & - & - \\
\hline Arnot & - & 5 & 2 & 3.3 & - & - & - \\
\hline \multicolumn{8}{|l|}{ Limpopo } \\
\hline Levubu & 961 & 4 & 1 & 4.0 & - & - & - \\
\hline \multicolumn{8}{|l|}{ North West } \\
\hline Lichtenburg & 1480 & 4 & 1 & 4.0 & 7 & 1 & 3.5 \\
\hline Ventersdorp & 1450 & - & - & - & 7 & 1 & 3.5 \\
\hline Grootpan & 1350 & 0 & 0 & 0 & 6 & 1 & 3.0 \\
\hline Rysmierbult & 1350 & 7 & 1 & 7.0 & - & - & - \\
\hline
\end{tabular}

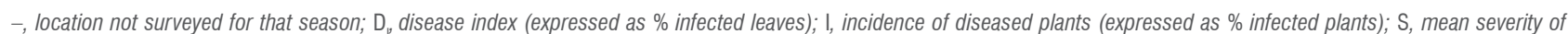
foliar symptoms (expressed as \% infected leaf area).

Disease severity was evaluated on a 1-9 scale, where $1=0 \%$ foliage affected, $3=2 \%$ foliage affected, $5=5 \%$ foliage affected, $7=10 \%$ foliage affected and $9=25 \%$ foliage affected. 24 
Table 2: $\quad$ Occurrence of bacterial brown spot in dry bean strip trials of South Africa

\begin{tabular}{|c|c|c|c|c|c|c|c|}
\hline \multirow[t]{3}{*}{ Location } & \multirow{3}{*}{$\begin{array}{l}\text { Altitude }^{\dagger} \\
\text { (m) }\end{array}$} & \multicolumn{6}{|c|}{ Season } \\
\hline & & \multicolumn{3}{|c|}{$2008 / 2009$} & \multicolumn{3}{|c|}{ 2010/2011 } \\
\hline & & I (\%) & $S(\%)$ & $D_{1}(\%)$ & I (\%) & $S(\%)$ & $D_{1}(\%)$ \\
\hline \multicolumn{8}{|l|}{ KwaZulu-Natal } \\
\hline Vryheid & 1190 & 22 & 3 & 16.5 & - & - & - \\
\hline \multicolumn{8}{|l|}{ Mpumalanga } \\
\hline Middelburg & 1447 & - & - & - & 7 & 2 & 7.0 \\
\hline \multicolumn{8}{|l|}{ North West } \\
\hline Grootpan & 1350 & - & - & - & 0 & 0 & 0 \\
\hline
\end{tabular}

'Sources: altitude $e^{33-37}$

-, location not surveyed for that season; $\mathrm{D}_{p}$ disease index (expressed as \% infected leaves); I, incidence of diseased plants (expressed as \% infected plants); $\mathrm{S}$, mean severity of foliar symptoms (expressed as \% infected leaf area).

Disease severity was evaluated on a $1-9$ scale, where $1=0 \%$ foliage affected, $3=2 \%$ foliage affected, $5=5 \%$ foliage affected, $7=10 \%$ foliage affected and $9=25 \%$ foliage affected. ${ }^{24}$

Table 3: Occurrence of bacterial brown spot in dry bean national cultivar trials of South Africa

\begin{tabular}{|c|c|c|c|c|c|c|c|}
\hline \multirow[t]{3}{*}{ Location } & \multirow{3}{*}{$\begin{array}{l}\text { Altitude }^{\dagger} \\
\text { (m) }\end{array}$} & \multicolumn{6}{|c|}{ Season } \\
\hline & & \multicolumn{3}{|c|}{$2008 / 2009$} & \multicolumn{3}{|c|}{ 2010/2011 } \\
\hline & & I (\%) & $S(\%)$ & $D_{l}(\%)$ & I (\%) & $S(\%)$ & $D_{l}(\%)$ \\
\hline \multicolumn{8}{|l|}{ KwaZulu-Natal } \\
\hline Cedara & 1052 & 8 & 3 & 6.0 & 11 & 3 & 8.3 \\
\hline \multicolumn{8}{|l|}{ Free State } \\
\hline Warden & 1375 & 25 & 4 & 20.0 & - & - & - \\
\hline Fouriesburg & - & 19 & 4 & 19.0 & - & - & - \\
\hline Sterkfontein & 1629 & - & - & - & 15 & 3 & 11.3 \\
\hline Clocolan & 1600 & 5 & 2 & 3.3 & - & - & - \\
\hline Ficksburg & 1585 & 14 & 3 & 10.5 & - & - & - \\
\hline \multicolumn{8}{|l|}{ Mpumalanga } \\
\hline Delmas & 1571 & 16 & 3 & 12.0 & 14 & 3 & 14.0 \\
\hline Ermelo & 1735 & 22 & 3 & 16.5 & 15 & 2 & 10.0 \\
\hline Ermelo West & 1735 & 6 & 1 & 3 & - & - & - \\
\hline Bethal & 1590 & 21 & 3 & 15.8 & 22 & 3 & 22.0 \\
\hline Middelburg & 1447 & - & - & - & 12 & 2 & 8.0 \\
\hline \multicolumn{8}{|l|}{ North West } \\
\hline Lichtenburg & 1480 & 11 & 2 & 7.3 & 8 & 1 & 4.0 \\
\hline Ventersdorp & 1450 & - & - & - & 7 & 2 & 4.7 \\
\hline Grootpan & 1350 & 1 & 2 & 8.0 & 9 & 2 & 6.0 \\
\hline Rysmierbult & 1350 & 15 & 1 & 7.5 & - & - & - \\
\hline
\end{tabular}

${ }^{\dagger}$ Sources: altitude $e^{33-37}$

-, location not surveyed for that season; $\mathrm{D}_{p}$ disease index (expressed as \% infected leaves); I, incidence of diseased plants (expressed as \% infected plants); $\mathrm{S}$, mean severity of foliar symptoms (expressed as \% infected leaf area).

Disease severity was evaluated on a $1-9$ scale, where $1=0 \%$ foliage affected, $3=2 \%$ foliage affected, $5=5 \%$ foliage affected, $7=10 \%$ foliage affected and $9=25 \%$ foliage affected. ${ }^{24}$ 
was assessed in 10 randomly selected plants in home gardens and per row in subsistence farming systems. Disease incidence and severity were evaluated as described above and the disease index was calculated.

\section{Disease severity rating}

Disease severity was evaluated on each plant using a modified 1 to 9 International Center for Tropical Agriculture scale, where $1=0 \%$ foliage affected, $3=2 \%$ foliage affected, $5=5 \%$ foliage affected, $7=10 \%$ foliage affected and $9=25 \%$ foliage affected. ${ }^{24}$

\section{Isolation and identification of bacterial brown spot pathogen}

A total of 378 diseased leaf samples were collected and used to isolate the BBS pathogen, PSs. Leaves were rinsed under running tap water for approximately $10 \mathrm{~min}$, surface sterilised for $3 \mathrm{~min}$ in $3.5 \%$ sodium hypochlorite and rinsed twice in sterile water for $1 \mathrm{~min}$ at a time. Leaves were macerated in a droplet of sterile water and the macerate was streaked onto King's B agar..$^{25}$ Plates were incubated for $48-72 \mathrm{~h}$ at $25^{\circ} \mathrm{C}$.

Fluorescent colonies typical of Pseudomonas spp. were selected under UV light and incubated for $48 \mathrm{~h}$ on King's B medium for purification. Isolates were tested for oxidase (-) and levan production (+). ${ }^{26}$ Carbon source utilisation of sucrose, mannitol, sorbitol and inositol was used to distinguish Pss from P. syringae pv. phaseolicola (Psp) isolates. ${ }^{27}$ Isolates were subjected to the LOPAT test, ${ }^{28}$ the analytical profile index 20E (bioMerieux, Marcy l'Etoile, France) and Biolog GN Microplate (Biolog, Hayward, CA, USA) analyses. Agglutination of PSS-specific antiserum antibody (Express Kit, NEOGEN Europe Ltd., Scotland, UK) confirmed the identity of isolates.

\section{Results}

\section{Commercial fields}

Results from surveys conducted in commercial fields are given in Table 1. The BBS incidence, severity and disease index on commercial farms ranged from $0 \%$ to $15 \%, 0 \%$ to $3 \%$, and $0 \%$ to $7.5 \%$, respectively, during the 2008/2009 dry bean growing season (Table 1). During the 2010/2011 dry bean growing season, BBS incidence, severity and index ranged from $4 \%$ to $9 \%, 1 \%$ to $3 \%$, and $2.7 \%$ to $9 \%$, respectively. The disease was most severe at Warden (3\%) and Estcourt (3\%) during the 2008/2009 season and at Warden (3\%) and Sterkfontein (3\%) during the $2010 / 2011$ dry bean growing season. Generally, BBS occurred on $96 \%$ of commercial farms during the two seasons.

\section{Strip trials}

Results from surveys conducted in strip trials are given in Table 2. During the 2008/2009 dry bean growing season, one strip trial was surveyed, in which BBS incidence was $22 \%$, severity $3 \%$ and the disease index was $16.5 \%$. Two strip trials in two localities were surveyed during the 2010/2011 dry bean growing season in which BBS incidence ranged from $0 \%$ to $7 \%$, severity from $0 \%$ to $2 \%$ and the index from $0 \%$ to $7 \%$. Of the two seasons surveyed, the disease was most severe at Vryheid (3\%) during the $2008 / 2009$ season. BBS was not recorded in the strip trial surveyed in Grootpan. BBS occurred in $67 \%$ of strip trials during the two seasons.

\section{National cultivar trials}

Results from surveys conducted in national cultivar trials are given in Table 3. BBS incidence ranged from $1 \%$ to $25 \%$, severity from $1 \%$ to $4 \%$, and index from $3 \%$ to $20 \%$ during the $2008 / 2009$ dry bean growing season in the national cultivar trials (Table 3). BBS incidence ranging from $7 \%$ to $22 \%$, severity from $1 \%$ to $3 \%$ and index from $4 \%$ to $22 \%$ were recorded during the 2010/2011 dry bean growing season. BBS occurred in all the national cultivar trials surveyed over the two seasons. Disease severity was highest at Warden (4\%) and Fouriesburg (4\%) (2008/2009), followed by Cedara (3\%), Sterkfontein (3\%), Delmas (3\%) and Bethal (3\%) (2010/2011). BBS occurred in $100 \%$ of national cultivar trials during the two seasons.

\section{Subsistence farms}

Results from surveys conducted on subsistence farms are given in Table 4. BBS incidence, severity and index ranged from $0 \%$ to $7 \%, 0 \%$ to $2 \%$, and $0 \%$ to $7 \%$, respectively, during the $2008 / 2009$ dry bean growing season. BBS incidence, severity and index ranged from $0 \%$ to $8 \%, 0 \%$ to $2 \%$, and $0 \%$ to $8 \%$ during the $2010 / 2011$ dry bean growing season. BBS was observed in up to $46 \%$ of subsistence farms. Ohrigstad (2\%) and Mgwagwa (2\%), respectively, had the highest disease severity during the

Table 4: $\quad$ Occurrence of bacterial brown spot in dry bean subsistence farms of South Africa

\begin{tabular}{|c|c|c|c|c|c|c|c|}
\hline \multirow[t]{3}{*}{ Location } & \multirow{3}{*}{$\begin{array}{c}\text { Altitude }^{\dagger} \\
\text { (m) }\end{array}$} & \multicolumn{6}{|c|}{ Season } \\
\hline & & \multicolumn{3}{|c|}{$2008 / 2009$} & \multicolumn{3}{|c|}{$2010 / 2011$} \\
\hline & & I (\%) & $S(\%)$ & $D_{1}(\%)$ & $I(\%)$ & $S(\%)$ & $D_{1}(\%)$ \\
\hline \multicolumn{8}{|l|}{ KwaZulu-Natal } \\
\hline Mpande & - & 0 & 0 & 0 & 3 & 1 & 1.5 \\
\hline Ohrigstad & - & 7 & 2 & 7.0 & - & - & - \\
\hline Mgwagwa & - & - & - & - & 8 & 2 & 8.0 \\
\hline \multicolumn{8}{|l|}{ Limpopo } \\
\hline Rabali & 961 & 3 & 1 & 3.0 & 3 & 1 & 3.0 \\
\hline Matanda & 961 & 0 & 0 & 0 & 0 & 0 & 0 \\
\hline Tshiombo & 600 & - & - & - & 0 & 0 & 0 \\
\hline Sekororo & 880 & 4 & 1 & 4.0 & 3 & 1 & 3.0 \\
\hline Vertilis & 880 & - & - & - & 0 & 0 & 0 \\
\hline Maraxwe & 600 & 0 & 0 & 0 & - & - & - \\
\hline
\end{tabular}

'Sources: altitude ${ }^{33-37}$

-, location not surveyed for that season; $\mathrm{D}_{\mu}$ disease index (expressed as \% infected leaves); I, incidence of diseased plants (expressed as \% infected plants); $\mathrm{S}$, mean severity of foliar symptoms (expressed as \% infected leaf area).

Disease severity was evaluated on a $1-9$ scale, where $1=0 \%$ foliage affected, $3=2 \%$ foliage affected, $5=5 \%$ foliage affected, $7=10 \%$ foliage affected and $9=25 \%$ foliage affected. ${ }^{24}$ 
$2008 / 2009$ and $2010 / 2011$ dry bean growing seasons. BBS occurred in $54 \%$ of subsistence farms during the two seasons.

\section{Isolation and identification of bacterial brown spot pathogen}

Pss was positively identified in $82 \%$ of the 378 leaf samples from the $2008 / 2009$ and $2010 / 2011$ seasons combined that were subjected to the pathogen isolation procedure. Isolates were stored at $-70^{\circ} \mathrm{C}$ following standard procedure and kept for the pathogen characterisation study.

\section{Discussion}

Bacterial brown spot incidences and severities varied over seasons at the same locations and over different locations in the same seasons. BBS was observed in $88 \%$ of all the locations surveyed. BBS was observed in up to $96 \%$ of commercial farms (Table 1), $67 \%$ of strip trials (Table 2 ), $100 \%$ of national cultivar trials (Table 3 ) and $46 \%$ of subsistence farms (Table 4). Although BBS severities were low, incidences were high $(0 \%$ to $25 \%$ ) in the majority of the locations surveyed. This study confirms that BBS is widely distributed in the dry bean production areas of South Africa, which corresponds with previous reports. ${ }^{2,17}$

Almost all of South Africa's dry bean production takes place in the provinces in which the surveys were conducted. The high incidence of the disease in these areas may have an effect on dry bean quantity and quality. It is possible that the majority of infections was a result of seed infections as it has been previously reported that BBS poses a particularly serious threat in the disease-free seed scheme ${ }^{29}$, from which seed is obtained.

Higher BBS incidences and severities, respectively, were recorded in KwaZulu-Natal (22\% and 3\%), the Free State (25\% and $4 \%$ ) and Mpumalanga (22\% and $3 \%$ ) compared with those of other provinces. The Free State and Mpumalanga Provinces are the largest dry bean producing provinces of South Africa (Figure 1). BBS incidences and subsequent severities were consistently and continuously observed in dry bean production and experimental fields of South Africa. ${ }^{2,16,17}$ BBS occurred in $100 \%$ of commercial fields with a disease incidence of up to $100 \%$ while severity was generally low $(1-2) .{ }^{2}$ The annual average rainfall is highest in KwaZulu-Natal $(845 \mathrm{~mm})$, Mpumalanga $(736 \mathrm{~mm})$ and the Free State $(532 \mathrm{~mm})$, compared with other provinces surveyed (Table 5). The high rainfall and subsequent humidity in these areas could have favoured BBS occurrence and severity as suggested by Hagedorn and Inglis ${ }^{6}$. Population increases of Pss of almost 100-fold from 34-35 days after planting after $26 \mathrm{~mm}$ rainfall have been reported. ${ }^{30}$ The converse of this notion is supported by the lower BBS incidences in Limpopo and the North West Provinces, which are among the most arid provinces of South Africa with average annual rainfalls of $527 \mathrm{~mm}$ and $481 \mathrm{~mm}$, respectively (Table 5). Low BBS incidences $(0-7 \%)$ on the majority of the subsistence farms (Table 4) could be explained by the lower humidity that characterises these areas.

Table 5: $\quad$ Average weather data and approximate latitudes and longitudes of dry bean producing areas surveyed in South Africa

\begin{tabular}{l|c|c|c}
\hline \hline \multicolumn{1}{|c|}{ Location } & $\begin{array}{c}\text { Average annual } \\
\text { rainfall } \\
(\mathbf{m m})\end{array}$ & $\begin{array}{c}\text { Average annual } \\
\left.\text { temperature } \mathbf{(}^{\circ} \mathbf{C}\right)\end{array}$ & $\begin{array}{c}\text { Approximate } \\
\text { latitude and } \\
\text { longitude }\end{array}$ \\
\hline \hline KwaZulu-Natal & 845 & 15.8 & $29^{\circ} 00^{\prime} \mathrm{S} 31^{\circ} 00^{\prime} \mathrm{E}$ \\
\hline Free State & 532 & 15.8 & $28^{\circ} 30^{\prime} \mathrm{S} 27^{\circ} 00^{\prime} \mathrm{E}$ \\
\hline Mpumalanga & 736 & 17.1 & $26^{\circ} 00^{\prime} \mathrm{S} 30^{\circ} 00^{\prime} \mathrm{E}$ \\
\hline Limpopo & 527 & 20.0 & $24^{\circ} 00^{\prime} \mathrm{S} 29^{\circ} 00^{\prime} \mathrm{E}$ \\
\hline North West & 481 & 18.3 & $27^{\circ} 00^{\prime} \mathrm{S} 26^{\circ} 00^{\prime} \mathrm{E}$ \\
\hline
\end{tabular}

Sources: average annual rainfall and temperature ${ }^{38}$; approximate latitude and longitud e $33.37^{37}$
With the exception of the Free State Province, the Limpopo and North West Provinces generally had lower BBS incidences and severities, and are characterised by average annual temperatures (Table 5) of at least $18.3^{\circ} \mathrm{C}$. This observation could therefore imply that very high temperatures might contribute to lower BBS incidences and severities.

Pss is one of the few bacterial species with the ability to inhabit the host leaf surface without causing disease.$^{31}$ However, frost injury can occur because Pss has the ability to catalyse ice formation at temperatures above $-5{ }^{\circ} \mathrm{C} .{ }^{32}$ The results discussed here do not take into account epiphytic cells that could have been present on the leaf surfaces, even on leaves appearing healthy.

Low disease severities could also be attributed to the fact that many commercial farmers plant disease-free seed. As Pss is seed-borne, it continues to be a threat because a number of producers, mainly subsistence farmers, still plant their own seed, which can impact the spread of the disease in seasons in which conditions are conducive for the spread of disease.

The findings of this study indicate recurring incidences of high proportions in commercial farms, as reported previously. ${ }^{2}$ High BBS incidences in strip and national cultivar trials and in subsistence farms and home gardens were also high, which could be attributed to continuous use of contaminated seed. The current BBS incidences and severities signify the importance for the development, through backcross breeding, of BBS-resistant dry bean cultivars if incidences and severities of greater proportions are to be avoided, thereby ensuring sustained dry bean production in South Africa.

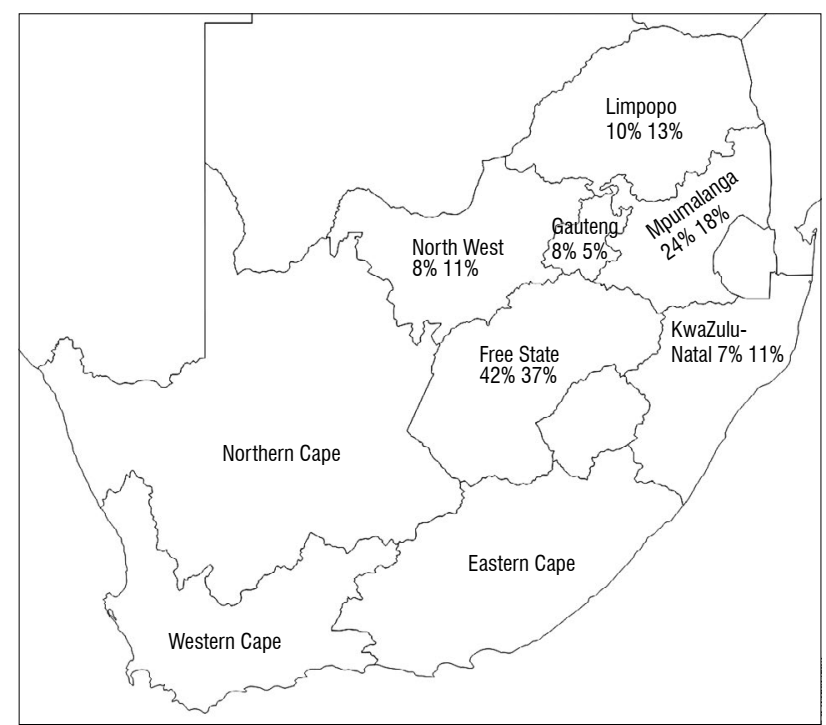

Figure 1: Dry bean production levels in the six main production provinces of South Africa during the 2008/2009 (left value) and 2010/2011 (right value) growing seasons.

\section{Acknowledgements}

We thank the National Research Foundation and the Department of Science and Technology of South Africa for their financial contributions; the Agricultural Research Council for their financial contribution and the provision of research facilities and other resources; and the South African dry bean farmers who gave permission to access their farms.

\section{Authors' contributions}

H.T.H.M. was the student project leader, D.F. was the student mentor and co-promoter, and N.W.M. was the student promoter. H.T.H.M. conducted the experiment and wrote the manuscript, D.F. advised on initiating the experiment and contributed to the write-up, and N.W.M. contributed to the write-up. 


\section{References}

1. Brick MA, Grafton KF. Improvement of medium-seeded race Durango cultivars. In: Singh SP, editor. Common bean improvement in the twenty-first century. London: Kluwer Academic Publishers; 1999. p. 223-253. http:// dx.doi.org/10.1007/978-94-015-9211-6_9

2. Fourie D. Distribution and severity of bacterial diseases on dry beans (Phaseolus vulgaris) in South Africa. J Phytopath. 2002;150:220-226. http://dx.doi.org/10.1046/j.1439-0434.2002.00745.x

3. Harveson RM, Schwartz HF. Bacterial diseases of dry edible beans in the Central High Plains. Plant Health Prog [serial on the Internet]. 2007 January 25 [cited 2015 Mar 03]. Available from: http://www.plantmanagementnetwork. org/pub/php/diagnosticguide/2007/beans

4. Dillard HR, Legard DE. Vegetable crops: Bacterial diseases of beans [homepage on the Internet]. c1991 [cited 2015 Mar 03]. Available from: http://vegetablemdonline.ppath.cornell.edu/factsheets/Beans_Bacterial.htm

5. Bradbury JF. Guide to plant pathogenic bacteria. Farnham Royal, UK: CAB International; 1986

6. Hagedorn DJ, Inglis DA. Handbook of bean diseases. Madison, Wl: University of Wisconsin; 1986.

7. Saettler AW. Diseases caused by bacteria. In: Schwartz HF, Steadman JR, Hall R, Forster RL, editors. Compendium of bean diseases. 2nd ed. St. Paul, MN: American Phytopathological Society; 2005. p. 46-47.

8. Schwartz HF. Bacterial diseases of beans. Fact sheet number 2.913 [homepage on the Internet]. c2012 [cited 2015 Mar 03]. Available from: http://www.ext.colostate.edu/pubs/crops/02913.html

9. Franc GD. Bacterial diseases of beans. Laramie, WY: University of Wyoming; 1998

10. Schwartz HF, Gent DH, Franc GD, Harveson RM. Bacterial brown spot [homepage on the Internet]. c2005 [cited 2007 Dec 06]. Available from: http://wiki.bugwood.org/HPIPM:Bacterial_Brown_Spot

11. Garrett KA, Schwartz HF. Epiphytic Pseudomonas syringae on dry beans treated with copper-based bactericides. Plant Dis. 1998;82:30-35. http://dx.doi.org/10.1094/PDIS.1998.82.1.30

12. Legard DE, Hunter JE. Pathogenicity on bean of Pseudomonas syringae pv. syringae recovered from the phylloplane of weeds and from bean crop residue. Phytopathology. 1990;80:938-942. http://dx.doi.org/10.1094/Phyto-80-938

13. Singh SP. Improvement of small-seeded race Mesoamerica cultivars. In: Singh SP, editor. Common bean improvement in the twenty-first century. London: Kluwer Academic Publishers; 1999. p. 255-274. http://dx.doi. org/10.1007/978-94-015-9211-6_10

14. Autrey LJC, Saumtally S. Identification of components of the bacterial blight complex of bean in Mauritius, their relative importance and measures adopted for their control. CIAT African Workshop Series. 1990;7:236-250. Cited by: Serfontein JJ. Occurrence of bacterial brown spot of dry beans in the Transvaal Province of South Africa. Plant Path. 1994;43:597-599. http://dx.doi.org/10.1111/j.1365-3059.1994.tb01595.x

15. Fourie D. Brown spot of dry edible beans. In: Coutinho TA, Goszczynska T, Lennox C, Venter SN, editors. Bacterial diseases of plants in South Africa. Pretoria: Briza Publications; 2009. p. 101-102

16. Melis RJM. Diseases and pest problems of beans (Phaseolus vulgaris) in South Africa. Occasional Publication No. 7. Pietermaritzburg: Department of Crop Science, University of Natal; 1987.

17. Serfontein JJ. Occurrence of bacterial brown spot of dry beans in the Transvaal Province of South Africa. Plant Path. 1994;43:597-599. http://dx.doi.org/10.1111/j.1365-3059.1994.tb01595.x

18. Cooksey DA. Genetics of bactericide resistance in plant pathogenic bacteria. Ann Rev Phytopath. 1990;28:201-219. http://dx.doi.org/10.1146/annurev. py.28.090190.001221
19. Vanneste JL, Voyle MD. Characterisation of transposon genes and mutations which confer streptomycin resistance in bacterial strains isolated from New Zealand orchards. Acta Hort. 2001;590:493-495

20. Liebenberg AJ, Du Plessis MJ, Fourie D, Liebenberg MM, Van Zyl CJ. Dry bean production [homepage on the Internet]. c2002 [cited 2015 Mar 03]. Available from: http://www.nda.agric.za/docs/drybean/drybean.htm

21. Agricultural Statistics. Dry beans: Market value chain profile 2010/2011 [document on the Internet]. c2011 [cited 2015 Mar 03]. Available from: http://www.nda.agric.za/docs/amcp/drybeanmvcp2010-2011.pdf

22. Department of Agriculture, Forestry and Fisheries. Dry beans: Production guideline [document on the Internet]. c2010 [cited 2015 Mar 03]. Available from: http://www.nda.agric.za/docs/Brochures/prodGuideDryBeans.pdf

23. Bejarano-Alc 'azar J, Blanco-L'opez MA, Melero-Vara JM, Jim 'enez-D' Iaz RM. Etiology, importance, and distribution of verticillium wilt of cotton in southern Spain. Plant Dis. 1996;80:1233-1238. http://dx.doi.org/10.1094/ PD-80-1233

24. Van Schoonhoven A, Pastor-Corrales MA. Standard system for the evaluation of bean germplasm. Cali, Colombia: International Center for Tropical Agriculture; 1987. p. 53

25. King E0, Ward MK, Raney DE. Two simple media for the demonstration of pyocyanin and fluorescin. J Lab Clin Med. 1954;44:301-307.

26. Bull CT, Goldman PH, Cintas NA, Koike, S. Identification of Pseudomonas species from a variety of hosts in the Salinas Valley of California. In International Conference on Pseudomonas syringae Pathovars; 2002 September 15-19; Acquafredda di Maratea, Italy. Dordrecht: Springer Science+Business Media B.V.; 2003. p. 607-615.

27. Hildebrand DC, Schroth MN, Sands DC. Pseudomonas. In: Schaad NW editor. Laboratory guide for identification of plant-pathogenic bacteria. 2nd ed. St. Paul, MN: American Phytopathological Society; 1988. p. 81-93.

28. Natalini E, Rossi MP, Barionovi D, Scortichini M. Genetic and pathogenic diversity of Pseudomonas syringae pv. syringae isolates associated with bud necrosis and leaf spot of pear in a single orchard. J Plant Path. 2006;88:219-223.

29. Fourie D. Susceptibility of South African dry bean cultivars to bacteria diseases. Afr Crop Sci J. 2011;19:387-392.

30. Hirano SS, Rousse DI, Clayton M, Upper CD. Pseudomonas syringae pv. syringae and bacterial brown spot of snap bean: A study of epiphytic phytopathogenic bacteria and associated disease. Plant Dis. 1995;79:1085-1093. http://dx.doi.org/10.1094/PD-79-1085

31. Hirano SS, Upper CD. Bacterial in the leaf ecosystem with emphasis on Pseudomonas syringae - A pathogen, ice nucleus, and epiphyte. Microbiol Mol Biol Rev. 2000;64:624-653. http://dx.doi.org/10.1128/MMBR.64.3.624-653.2000

32. Lindow SE, Anderson G, Beattie GA. Characteristics of insertional mutants of Pseudomonas syringae with reduced epiphytic fitness. Appl Environ Microbiol. 1993;59:1593-1601.

33. Free State (province) [homepage on the Internet]. No date [cited 2015 Mar 12]. http://en.wikipedia.org/wiki/Free_State_(province)

34. KwaZulu-Natal [homepage on the Internet]. No date [cited 2015 Mar 12]. http://en.wikipedia.org/wiki/KwaZulu-Natal

35. Limpopo [homepage on the Internet]. No date [cited 2015 Mar 12]. http://en.wikipedia.org/wiki/Limpopo

36. Mpumalanga [homepage on the Internet]. No date [cited 2015 Mar 12]. http://en.wikipedia.org/wiki/Mpumalanga

37. North West (South African province) [homepage on the Internet]. No date [cited 2015 Mar 12]. http://en.wikipedia.org/wiki/North_West_(South_ African_province)

38. Durand W. Assessing the impact of climate change on crop water use in South Africa [document on the Internet]. No date [cited 2015 Mar 12]. Available from: http://www.ceepa.co.za/uploads/files/CDP28.pdf 